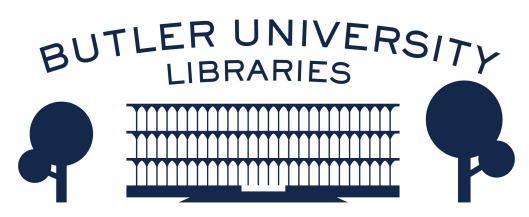

Journal of Hindu-Christian Studies

Volume 6

Article 18

January 1993

\title{
Book Review: "Theology After Vedanta: An Experiment in Comparative Theology"
}

Harold Coward

Follow this and additional works at: https://digitalcommons.butler.edu/jhcs

Part of the Religion Commons

\section{Recommended Citation}

Coward, Harold (1993) "Book Review: "Theology After Vedanta: An Experiment in Comparative Theology"," Journal of Hindu-Christian Studies: Vol. 6, Article 18.

Available at: https://doi.org/10.7825/2164-6279.1087

The Journal of Hindu-Christian Studies is a publication of the Society for Hindu-Christian Studies. The digital version is made available by Digital Commons @ Butler University. For questions about the Journal or the Society, please contact cbauman@butler.edu. For more information about Digital Commons @ Butler University, please contact digitalscholarship@butler.edu. 


\section{Theology After Vedanta: An Experiment in Comparative Theology. Francis X. Clooney, S.J., Albany: State University of New York Press, 1993, XVIII+265pp., $\$ 14.95$ paper, $\$ 44.50$ hardcover.}

THIS IS A TRULY original and important book. It shows that people live from the world of scripture rather than from the dogmas that scripture may generate. It is also a most original and successful experiment in comparative theology. Clooney's aim is 'the delineation of a better way that is more practical, more engaged in texts and in the concreteness of multiple theological traditions ...' (p.2). What is offered is nothing short of a new way of doing theology which is at once comparative and based upon the careful reading of scriptures and commentaries. The comparative aspect is focused on the Hindu Advaita Vedanta commentarial tradition which is read together with the Christian Summa Theologiae of Thomas Aquinas.

What Clooney offers is more than simply a comparison, it is also a sensitive and original exploration of how in such a study the reader moves from the status of 'observer' to 'participant' and the impact of this shift upon one's experience of truth. A further contribution is Clooney's clear demonstration that, contrary to most scholarship on Advaita Vedanta, what Sankara offers us is not philosophy but theology - a theology deeply embedded in an exegetical or commentarial tradition. In his analysis Clooney gives us a fresh presentation of the content, character and soteriology of Advaita Vedanta (chapters 2-4). The concluding chapter is devoted to the reflective comparison of this new understanding of Advaita with the Summa of Aquinas resulting in an enriched understanding of the latter. In short the end result is a rethinking and rewriting of Christian theology after a close reading of Advaita Vedanta.

In Chapter One the author sets out in systematic fashion the key elements of his approach to doing comparative theology. This chapter is so insightful that it could well be used as a text for students studying comparative methodology. It is in tune with modern hermeneutics in that Clooney's focus throughout is on 'how learning, writing and true knowledge follow from patient reading ...' (p.2). A method for balancing an engagement of an 'other' tradition through reading and through the reappraisal of one's own position is outlined. Clooney's comparative theology moves one beyond the mere cataloguing of different traditions for their similarities or differences. It pushes one to grapple with questions of the truth of one's own or of others' knowledge of God - this is what makes his method 'theological'. But the motivation is not to see whose truth wins out, rather 'comparative theology' aims at the rereading and rewriting of one's own truth from the outside perspective of another tradition - in this case the rewriting of Catholic theology from the reading of the Summa in the context of Advaita. This is not an easy method, for it requires of the theologian the hard linguistic and Indological study necessary for a credible reading of the Advaita texts. But unlike much Indological and Religious Studies methodology, Clooney's approach is throughout invested with the dimension of faith. As he observes, 'The faith of the inquirer cannot be separated from the faith claims of the inquirer's community; this faith is explicitly at issue in the comparative exercise, as much as a concern for truth that may emerge and claim the scholar more or less profoundly during the project of comparison' (p.8). Thus Clooney distinguishes the study of religion and its goal of sympathetically understanding another religion from the goal of comparative theology which aims at a critical restating of 
one's own beliefs in the context of the nonreductionist reading of another's tradition. In this sense comparative theology results in practical rather than theoretical knowledge it opens one to the possibility of being transformed through the process of comparative reading and writing. It is in this sense that Clooney talks of moving 'from reader as observer to reader as participant' (pp.34-5).

Chapter Two offers a close examination of the texture of the Advaita text. The Upanishads upon which the Advaita commentaries depend are shown to evoke the teacher-student context and the proper relation of oneself to the world. What they offer is not to be passively received nor is it mere information, rather, it is new knowledge the student must gain through direct experience. Clooney shows that the approach of the Upanishads in raising questions that are not entirely answered is preserved and extended in Advaita texts. He then goes on to examine the forms of Advaita text - sutra and adhikarana - and how they function in relation to the original Upanishads. They are shown to lead to an ever-deeper reading of the text as well as a widened understanding of the passage in the context of those coming before and after it (p.48).

The way in which this process works in Badarayana's systematisation of the Upanishadic text and the later commentaries of Sankara and others is well demonstrated in Clooney's careful tracing of specific example texts such as Taittiriya 2.1-6a ('Is Brahman the fifth sheath "consisting of bliss" or is it beyond that sheath?'). The author's aim in this close reading of Advaita texts is not just to provide a better insight into these ancient texts but to show that through this process the modern reader becomes a part of the exchange - the ancient process comes alive as one participates in it, offering new clarifications and posing new questions. It is in this way that the revealed text of the Upanishad is kept fresh and relevant in its constant evolution through the commentarial process. The role of reason in this intricate process is also examined (pp.63-74) to show its function in determining the main meaning of a text. Unlike the modern West where reason (as in Kant) functions ontologically to generate meaning, here reason is a technical tool that removes obstacles to seeing the given revelation of a text.

Although available to outsiders and moderns, the reading of Advaita texts, as Clooney demonstrates, is a slow and demanding process, which for the one willing to make the intellectual effort can be a pathway to truth. The way in which the extratextual truth of Brahman is realised through various reading strategies is described in Chapter Three. The truth claims of Advaita Vedanta are embedded in the Truth-Text-Reader complex relationship. The truth of Advaita is shown to be intertextual. Although language is limited it can, through the careful reading of Upanishads and commentaries, mediate knowledge of Brahman. Chapter Four offers a sensitive analysis of just how this truth about Brahman is mediated in the interaction between the Advaita texts and their readers.

Vacaspati Misra's analogy that learning to hear Brahman in the text is like learning to truly hear a note of music (p.126) is revealing. It also highlights one problem I have with Clooney's otherwise splendid presentation. He does not give enough attention to the oral hearing aspect of the Advaita process of having truth mediated through texts. Clooney's approach concentrates too much on careful reading at the expense of careful hearing through constant repetition of the sort suggested by Vacaspati's analogy. However, it may well be that the careful reading is 'hearing' the words read 'in the mind' so that the reading process of Advaita is functioning as a yogic repetition of the meaning mantra of the text.

In this chapter Clooney offers the best analysis I have seen on Sankara's famous prerequisite requirements for 'becoming a reader' (Brahmajijnasa). These are nicely integrated with the four stages of life which is the only way to have them make sense. The same may be said for the necessary 
inter-relation of ritual and textual knowledge. To his credit Clooney also takes up the traditional exclusivism and elitism of Advaita (its reading is open only to upper-caste males) and offers what he considers a 'loophole' - namely the fact that he, a Christian outsider, has been able (faithfully it would seem) to take part in the prescribed careful reading of Advaita texts. Even those who patiently read the text in English, he suggests, may be transformed by it.

In Chapter Five Clooney turns to the comparative task of the 'rereading and retrieval of one's prior theology after an appropriation of Vedanta' (p.153). This, he makes clear, is not a choosing from Advaita of a few ideas one likes, but rather, the process by which a Christian theologian begins to think again the entire range of problems and possibilities in the (Christian) theological tradition, after a serious engagement with the Advaita text' (p.153). In particular Clooney rereads the Summa Theologiae of Thomas Aquinas and its commentaries. This rereading is new in that it follows the Advaita approach of taking not just the original text of the Summa but also its commentaries as a larger corpus which is then read together with the Advaita Vedanta texts previously considered. The goal, as stated by Clooney, is to use 'the Summa Theologiae to clarify the changes that occur in the Christian reader who has engaged seriously in the reading of Advaita' (p.157). $\mathrm{He}$ further suggests that rather than a normative expression of the Christian worldview, the Summa in this comparativist experiment demonstrates the margins of that worldview when it is read in a larger context that neither its author nor its tradition intended. New aspects of Aquinas' thought are brought to the fore as especially important and relevant for today. Possibilities, hidden by centuries of familiarity may be uncovered by this process.

As an example, Clooney focuses on the Introductory Section of the Summa and the problem of how to name God when God is not subject to the limitation of names. A parallel reading is introduced with Amalananda's text dealing with the qualities of Brahman (p.163). After identifying some basic similarities and differences, Clooney outlines five strategies for reading the two texts together, two of which come from Advaita while the others include Wheelwright's understanding of metaphor and Derrida's notion of 'collage'. In Derrida's terminology the parallel reading of two such texts invokes the momentarily disorienting act of decontextualisation of the too familiar and the recontextualisation beyond the old margins. The result is productive of new insights which then must be tested out in continuing comparative theological analysis. As a test case of the method, the author considers a Christian text (the discussion of Christ's passion by Aquinas ST III.46-49) for which there seems to be no Advaita parallel, and concludes that even in the face of extreme dissimilarity 'there is no reason to end the reading' (p.179). As benefits of the comparative reading Clooney identifies the recovery of attention to biblical citations in the Summa (its exegetical quality) and a retrieving of the reading of the Summa's commentaries, especially that by Cardinal Cajentan on ST 1.13.4. Neither of these, says the author, are common approaches to Aquinas in current scholarship. A contribution of comparative theology is to cause one to look at precisely those aspects of one's tradition that are not current in contemporary scholarship.

A more substantive point is the question of how to deal with the confrontation over issues of truth that seems bound to occur in such a comparative reading of Christian and Hindu texts. Clooney counsels the patient deferral of such questions until after the comparison is complete. Then the question of the truth one discovers should be dealt with not as the simple restatement of an earlier position, but as a deepened understanding which will change the conceptualisation of truth if not its substance. The comparison tested out is Aquinas' claim that it is the passion of Christ that is the only source of 
salvation for the world and the Advaita teaching that knowledge of Brahman is all that is required. Clooney has not 'fudged' the tough question. But, even more to be admired, he does not leave it at the intellectual level only. After much patient reading, thinking and writing, the comparative theologian must go on to the practical experience of salvation or realisation (as the Advaitan would prefer to call it). The final goal is clearly soteriological or as a Hindu would put it the realisation of the yoga of knowledge. This is also why Clooney's project is theological rather than philosophical in nature. The chapter ends with a brief reflection on the requirements for the education of a comparative theologian.

Clooney conservatively calls this book an experiment in comparative theology. While not all experiments are successful, this one clearly is. This review has assumed considerable length due to the conviction of the reviewer that Clooney has moved us to a new paradigm for comparative study generally, and for theology in particular. This book needs to be read by theologians, Hindu and Christian, who wish to pursue their work in today's pluralistic context.
Clooney's experiment needs to be repeated by others using different texts, and the results compared. But, as Clooney warns, such work is demanding and requires much patient scholarly effort. In this, however, the approach proposed is not unlike the best science. Surely theologians and their students can be as dedicated as our colleagues in science - the potential goal may be as important as any scientific discovery. Frank Reynolds, in his Foreword (p. xvi) to the book puts it this way:

For theologians committed to a particular religious tradition, Theology After Vedanta opens a path toward a new kind of theology of religions. ... an inclusivist, comparatively oriented, potentially transformative theology of religions [that] could revitalise contemporary theological research and reflection not only in Christianity, but (with appropriate adaptations) in other religious traditions as well.

This is the single most important book I have read in a long while.

Harold Coward

University of Victoria

Victoria, Canada V8W 3P4

\section{Exploring the Christian-Hindu dialogue: A Visit with Bede Griffiths and Russill Paul. 55 Minute VHS Video. VHS video $\$ 19.95$ (U.S.); audiotape from video $\$ 6.95$ (U.S.); available from Inner Growth Books and Videos, Box 520, Chiloquin, OR 97624 USA.}

\author{
BEDE GRIFFITH'S VISION of renewal in \\ the Church includes the formation of small \\ lay Christian contemplative communities in \\ the West, open to different religious \\ traditions, yet firmly grounded in their own \\ traditions. \\ In the first part of this video, Father \\ Bede responds to a series of carefully posed \\ questions concerning his life in India as a
}

Christian sannyasi and how he sees lay communities developing.

Of particular interest are his comments on topics such as the doctrine of the Trinity and his experience of Advaita, Christian versus Hindu mysticism, and the difference between an ashram and a monastery.

In the second part, Russill Paul, a professional musician born in the Anglo- 